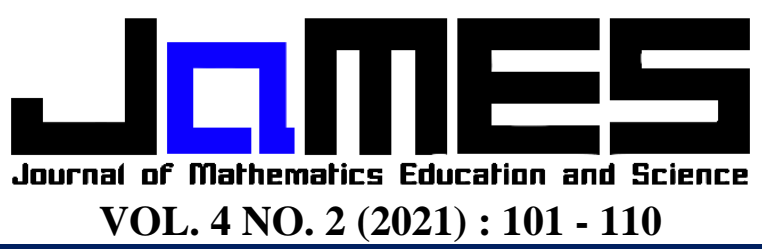

p-ISSN: 2621-1203 | https://doi.org/10.32665/james.v4i2.247 | e-ISSN: 2621-1211

\title{
PENGARUH METODE FLIPPED CLASSROOM BERBANTUAN SCHOOLOGY TERHADAP HASIL BELAJAR SISWA DITINJAU DARI KEMANDIRIAN BELAJAR
}

\author{
Najia $^{1}$, Iis Holisin ${ }^{2}$, Himmatul Mursyidah ${ }^{3}$ \\ Corresponding author : I. Holisin \\ Universitas Muhammadiyah Surabaya, najiaellsyauqy@ gmail.com ${ }^{1}$ \\ Universitas Muhammadiyah Surabaya, iis.irawan.1967@gmail.com² \\ Universitas Muhammadiyah Surabaya, himmatul.pendmat@fkip.um-surabaya.ac.id ${ }^{3}$ \\ Received : 19 Oktober 2021, Revised : 21 Oktober 2021, Accepted : 24 Oktober 2021 \\ (C) Mathematics Education Unugiri 2021
}

\begin{abstract}
The research aims to describe whether or not there is an effect of the flipped classroom learning method assisted by Schoology on students' learning outcomes, to investigate the influence between high learning independence and low learning independence on students' learning outcomes, to investigate the interaction of the use of learning methods and independence learning on students' learning outcomes, and to analyze student's activities. The research method used is a quasi-experimental method and uses a $2 \times 2$ factorial design with two-way analysis of variance conducted in VIII grade at junior high school Muhammadiyah 5 of Surabaya. The sample in the research was 54 students consisting of VIII-C grade and VIII-E grade. The results showed that the average of students' learning outcomes in the high and low learning independence categories were 91.00 and 82.00 in the experimental class, respectively, with the percentage of students' activity classically $66.07 \%$ in the sufficient category. While in the control class, the average of students' learning outcomes in the high and low learning independence categories were 81.053 and 69.625, respectively. Based on the two-way ANOVA test (two-way analysis of variance) shows that there is a significant difference between learning outcomes using the flipped classroom learning method assisted by Schoology and using e-learning which is commonly used in SMP Muhammadiyah 5 Surabaya with the help of Microsoft teams. There is an influence between high learning independence and low learning independence on students' learning outcomes. However, there is no interaction between learning methods and students' learning independence on students' learning outcomes at SMP Muhammadiyah 5 Surabaya.
\end{abstract}

Keywords: E-Learning, Learning Outcomes, Flipped Classroom Method, Schoology

\begin{abstract}
Abstrak
Penelitian ini bertujuan untuk menginvestigasi ada tidaknya pengaruh metode pembelajaran flipped classroom berbantuan schoology terhadap hasil belajar siswa, menginvestigasi pengaruh antara kemandirian belajar tinggi dan kemandirian belajar rendah terhadap hasil belajar siswa, menginvestigasi interaksi penggunaan metode pembelajaran dan kemandirian belajar terhadap hasil belajar siswa dan menganalisis aktivitas siswa. Metode penelitian yang digunakan adalah metode quasi eksperimen menggunakan rancangan factorial $2 \times 2$ dengan analisis ANAVA dua jalan yang dilakukan pada kelas VIII SMP Muhammadiyah 5 Surabaya. Sampel pada penelitian ini yaitu 54 siswa terdiri dari siswa kelas VIII-C dan kelas VIII-E. Hasil penelitian menunjukkan rata-rata hasil belajar siswa kategori kemandirian belajar tinggi dan rendah berturut-turut adalah 91,00 dan 82,00 di kelas eksperimen, dengan persentase aktivitas siswa secara klasikal 66,07\% dalam kategori cukup. Sedangkan pada kelas kontrol, rata-rata hasil belajar siswa kategori kemandirian belajar tinggi dan rendah adalah 81,053 dan 69,625. Berdasarkan uji ANAVA dua jalan menunjukkan bahwa terdapat perbedaan signifikan antara hasil belajar yang menggunakan metode pembelajaran flipped classroom berbantuan schoology dengan yang menggunakan pembelajaran e-learning yang umum digunakan di SMP Muhammadiyah 5 Surabaya. Terdapat pengaruh antara kemandirian belajar tinggi dan kemandirian belajar rendah terhadap hasil belajar siswa. Namun, tidak terdapat interaksi antara metode pembelajaran dan kemandirian belajar siswa terhadap hasil belajar siswa.
\end{abstract}

Kata kunci: E-Learning, Hasil Belajar, Metode Flipped Classroom, Schoology 


\section{Pendahuluan}

Masa pandemi Covid-19 mengharuskan sekolah-sekolah untuk melakukan pembelajaran jarak jauh melalui e-learning. Hasil belajar siswa SMP selama melakukan pembelajaran jarak jauh melalui e-learning di masa pandemi dapat dikatakan rendah khususnya pada pembelajaran matematika. Sebagaimana yang telah dijelaskan oleh Abdullah dkk, Legiman dan Tambunan pada penelitiannya bahwa hasil belajar matematika siswa SMP melalui pembelajaran daring selama pandemic Covid-19 masih termasuk dalam kategori kurang atau rendah $[1,2,3]$. Hal tersebut juga terjadi di SMP Muhammadiyah 5 Surabaya, berdasarkan wawancara yang dilakukan dengan guru matematika didapatkan fakta bahwa tujuan pembelajaran sulit untuk dicapai secara maksimal pada saat pembelajaran daring sehingga berdampak pada hasil belajar siswa menjadi kurang maksimal. Berdasarkan hasil observasi dan wawancara, hal tersebut terjadi akibat guru sulit memantau siswa pada saat proses pembelajaran, waktu pembelajaran sangat singkat hanya 45 menit dalam 1 pertemuan sehingga penyampaian materi sangat terbatas, sulit untuk dilakukan diskusi panjang dengan siswa, banyak siswa yang kurang bertanggung jawab atas tugasnya sehingga terlambat untuk mengumpulkan tugas bahkan terdapat siswa yang mengabaikan tugas yang diberikan.

Berdasarkan permasalahan tersebut dapat diketahui bahwa pemilihan metode, dan learning management system yang menunjang e-learning jarak jauh haruslah tepat. Sebagaimana pendapat Djamarah dalam Afandi dkk, bahwa metode pembelajaran dapat digunakan sebagai salah satu cara untuk mencapai tujuan pembelajaran yang telah ditetapkan [4]. Banyak metode pembelajaran yang dapat digunakan oleh guru, salah satunya adalah metode pembelajaran flipped classroom. Menurut Bergmann \& Sams yang dikutip oleh Kurniawati dkk, flipped classroom dimaknai sebagai kelas yang dibalik [5]. Selanjutnya, Kurniawidi menjelasakan bahwa dalam pembelajaran flipped classroom guru menggunakan media e-learning untuk mengunggah materi pembelajaran baik berupa dokumen ataupun video untuk dipelajari di rumah, kemudian ketika di kelas guru dan siswa hanya melakukan diskusi mengenai materi atau mengerjakan latihan soal yang memiliki tingkat kesulitan tinggi [6].

Kemandirian belajar juga menjadi salah satu unsur penting dalam pembelajaran berbasis $e$ learning untuk memaksimalkan proses pembelajaran dan memaksimalkan tujuan yang akan dicapai. Hal tersebut senada dengan pendapat Suid dkk dan Handayani dkk bahwa kemandirian belajar merupakan salah satu faktor yang menentukan keberhasilan siswa dalam belajar dan siswa yang memiliki tingkat kemandirian belajar yang baik maka akan memiliki hasil belajar yang maksimal $[7,8]$.

Menurut Jauhar, Amri, Nurdyansyah dkk, Elearning adalah suatu model pembelajaran yang melibatkan media teknologi komunikasi dan informasi seperti internet, $\mathrm{CD}$ interaktif atau HP sebagai metode penyampaian, interaksi, dan fasilitas guru dan siswa yang dapat dilakukan pada saat pertemuan di kelas maupun dilakukan untuk pembelajaran jarak jauh $[9,10,11]$. Penggunaan e-learning dalam pembelajaran dapat memudahkan pendidik dan peserta dalam melakukan proses pembelajaran karena dengan e-learning dapat dilakukan pembelajaran jarak jauh, dapat didapatkan informasi secara cepat, dan dapat diakses berbagai sumber belajar dengan mudah.

Saat ini, pendidik dapat dengan mudah mengakses laman-laman pembelajaran secara gratis maupun yang berbayar. Laman pembelajaran untuk penunjang e-learning yang dapat digunakan secara gratis salah satunya adalah schoology. Menurut Putri dkk, Schoology merupakan salah satu learning management system (LMS) berbentuk web sosial yang mudah digunakan karena bentuknya seperti facebook yang dapat digunakan sebagai pembelajaran sama seperti di kelas [12]. Sedangkan menurut Ulfi dkk, Schoology adalah jejaring sosial pribadi bagi guru dan siswa dengan platform sosial yang aman [13]. 
Penjelasan mengenai metode flipped classroom dipaparkan oleh Zatalini dkk dalam penelitiannya. Hasil belajar siswa yang menggunakan metode flipped classroom lebih tinggi dari siswa yang tidak menggunakan metode tersebut. Siswa juga lebih mandiri dalam mempelajari topik matematika dan mengerjakan lembar kerja siswa [14]. Penjelasan mengenai schoology juga dipaparkan oleh Choirudin dalam penelitiannya. Keaktifan siswa pada pembelajaran e-learning schoology berpengaruh positif terhadap hasil belajar siswa. Dimana rata-rata hasil belajar kelas eksperimen menggunakan schoology adalah $76,5 \%$ sedangkan rata-rata nilai kelas kontrol yang menggunakan pembelajaran kovensional adalah lebih rendah yaitu 70,23\% [15].

Berdasarkan uraian tersebut, maka penelitian ini dilakukan dengan menerapkan metode flipped classroom berbantuan schoology yang ditinjau dari kemandirian belajar siswa sebagai stimulus untuk meningkatkan hasil belajar siswa dari segi kognitif (prestasi siwa) dan segi afektif (aktivitas siswa). Tujuan dari penelitian ini adalah: (1) Mendeskripsikan ada tidaknya pengaruh metode pembelajaran flipped classroom berbantuan schoology terhadap hasil belajar siswa SMP Muhammadiyah 5 Surabaya. (2) Mendeskripsikan pengaruh antara kemandirian belajar tinggi dan kemandirian belajar rendah terhadap hasil belajar siswa SMP Muhammadiyah 5 Surabaya.

Mendeskripsikan interaksi penggunaan metode pembelajaran dan kemandirian belajar terhadap hasil belajar siswa SMP Muhammadiyah 5 Surabaya. (4) Mendeskripsikan aktivitas siswa dalam proses pembelajaran menggunakan metode flipped classroom berbantuan schoology.

\section{Metode Penelitian}

Penelitian ini merupakan penelitian quasi ekseprimen yang dilakukan terhadap siswa kelas VIII SMP Muhammadiyah 5 Surabaya pada semester genap tahun ajaran 2020/2021. Sampel dalam penelitian ini diambil menggunakan teknik Cluster Random Sampling dengan cara undian. Sampel penelitian yang diperoleh yaitu siswa kelas VIII-C dan kelas VIII-E. Jumlah keseluruhan sampel adalah 54 siswa. Kelas eksperimen pada kelas VIII-C yang terdiri dari 27 siswa dan kelas kontrol pada kelas VIII-E yang terdiri dari 27 siswa.

Teknik pengumpulan data yang digunakan adalah: (1) Tes tertulis, digunakan untuk mengetahui hasil belajar siswa dari segi kognitif. (2) Observasi, digunakan untuk mengetahui aktivitas siswa. (3) Penyebaran angket, digunakan untuk mengetahui kategori kemandirian belajar siswa.

Instrument penelitian yang digunakan antara lain: (1) Lembar tes hasil belajar siswa. Tes hasil belajar matematika siswa ini berbentuk tes tertulis. Tes ini diberikan dua kali yaitu pretest dan posttest. Pretest digunakan untuk melihat kemampuan awal siswa kelas eksperimen dan kelas kontrol sebelum diberi perlakuan khusus. Posttest digunakan untuk melihat kemampuan siswa kelas eksperimen dan kelas kontrol setelah diberi perlakuan khusus. Soal pretestposttest berbentuk soal uraian yang terdiri dari 3 soal. Uji coba instrumen pretest-posttest yang dilakukan mencakup uji validitas butir soal dan uji reliabilitas. Dari 3 soal yang diujicobakan diperoleh hasil bahwa ketiga soal tersebut valid dan reliabel. (2) Lembar observasi aktivitas siswa. Garis besar yang diobservasi adalah mendengarkan atau memperhatikan arahan dari guru, sikap pada saat pengerjaan pre-test dan post-test, berdiskusi antar siswa, bertanya ketika mengalami kesulitan, merumuskan masalah secara tepat, mengindentifikasi informasi dan data, merencanakan tindakan solusi. (3) Lembar angket. Angket yang diberikan berbentuk checklist. Skala angket yang digunakan dalam penelitian ini adalah summated rating scale (skala likert). Terdapat empat pilihan jawaban yang dikelompokkan dalam dua bentuk pilihan sesuai dengan pernyataan skala kemandirian. Opsi jawaban pilihannya yaitu selalu (SL), sering (SR), kadang-kadang (KD), dan tidak pernah (TP). Pertanyaan-pertanyaan yang diberikan berupa 
pernyataan positif dan negatif. Uji coba instrumen angket kemandirian belajar yang dilakukan meliputi uji validitas item dan uji reliabilitas. Angket kemandirian belajar yang diujicobakan terdiri dari 20 butir pernyataan dan diperoleh 18 butir pernyataan dengan kategori valid dan reliabel.

Data yang didapat pada penelitian ini adalah data kuantitatif pretest-posttest, angket kemandirian belajar, dan aktivitas siswa. Data pretest-posttest dan angket kemandirian belajar dianalisis menggunakan uji anva dua arah menggunakan rancangan faktorial $2 \times 2$ yang dapat dilihat pada Tabel 1.

Tabel 1. Rancangan Analisis Data

\begin{tabular}{ccc}
\hline Metode Pembelajaran & \multicolumn{2}{c}{ Kemandirian Belajar $(\mathrm{B})$} \\
\cline { 2 - 3 }$(\mathrm{A})$ & $\begin{array}{c}\text { Tinggi } \\
\left(\mathrm{B}_{1}\right)\end{array}$ & $\begin{array}{c}\text { Rendah } \\
\left(\mathrm{B}_{2}\right)\end{array}$ \\
\hline $\begin{array}{c}\text { Flipped Classroom } \\
\text { berbantuan Schoology }\left(\mathrm{A}_{1}\right)\end{array}$ & $\mathrm{A}_{1} \mathrm{~B}_{1}$ & $\mathrm{~A}_{1} \mathrm{~B}_{2}$ \\
\hline $\begin{array}{c}\text { Pembelajaran e-learning } \\
\text { yang umum digunakan di } \\
\text { SMP Muhammadiyah 5 }\end{array}$ & $\mathrm{A}_{2} \mathrm{~B}_{1}$ & $\mathrm{~A}_{2} \mathrm{~B}_{2}$ \\
$\begin{array}{c}\text { Surabaya dengan bantuan } \\
\text { Microsoft teams }\left(\mathrm{A}_{2}\right)\end{array}$ & & \\
\hline
\end{tabular}

Data aktivitas siswa dianalisis dengan cara menghitung persentase secara klasikal. Adapun rumus yang digunakan adalah sebagai berikut:

Persentase Aktivitas Siswa (Klasikal) = $\frac{\text { Spersentase aktivitas }}{\sum \text { aktitas }}$

¿aktivitas

Untuk mengetahui klasifikasi tingkat aktivitas siswa dapat dilihat pada Tabel 2.

Tabel 2. Klasifikasi Tingkat Aktivitas Siswa

\begin{tabular}{cc}
\hline Tingkat Keberhasilan & Kriteria Aktivitas \\
\hline$\geq 81 \%$ & Sangat aktif \\
\hline $70 \%-80 \%$ & Aktif \\
\hline $59 \%-69 \%$ & Cukup aktif \\
\hline $48 \%-58 \%$ & Kurang aktif \\
\hline$\leq 47$ & Tidak aktif \\
\hline & Sumber: [16]
\end{tabular}

Sebelum melakukan analisis data hasil belajar siswa, akan dilakukan uji analisis prasyarat dengan bantuan program SPSS yang mencakup uji keseimbangan data kemampuan awal siswa, uji normalitas, dan uji homogenitas. Kemudian dilakukan analisis data menggunakan uji ANAVA dua arah.

Berdasarkan hasil analisis uji keseimbangan dengan bantuan software SPSS versi 25.0 for windows diperoleh nilai sig $=0,503>\alpha=0,05$ dan nilai $t_{\text {hitung }}=0,674 \leq t_{\text {tabel }}=2,052$. Hal tersebut menunjukkan bahwa kemampuan awal siswa pada kelas kontrol dan kelas eksperimen berada pada kategori seimbang.

Uji analisis prasyarat selanjutnya yaitu uji normalitas dan uji homogenitas. Uji Levene digunakan pada uji normalitas dan pada uji homogenitas digunakan uji KolmogorofSmirnov (KS). Hasil pengolahan data dihitung dengan software SPSS versi 25.0 for windows diperoleh hasil sebagai berikut:

1) Uji normalitas

Hasil perhitungan diperoleh output dari analisis uji Kolmogorof-Smirnov (KS) normalitas data pretest kelas eksperimen dan kelas kontrol dapat dilihat pada tabel 3.

Tabel 3. Uji Normalitas Pretest Kelas Eksperimen dan Kelas Kontrol

\begin{tabular}{|c|c|c|c|c|c|c|c|}
\hline \multicolumn{8}{|c|}{ Tests of Normality } \\
\hline & \multirow{2}{*}{ Kelas } & \multicolumn{3}{|c|}{$\begin{array}{l}\text { Kolmogorov- } \\
\text { Smirnov }^{\mathrm{a}}\end{array}$} & \multicolumn{3}{|c|}{ Shapiro-Wilk } \\
\hline & & Statistic & $\mathrm{df}$ & Sig. & Statistic & $\mathrm{df}$ & Sig. \\
\hline $\begin{array}{l}\mathrm{Ha} \\
\text { sil } \\
\mathrm{Be}\end{array}$ & $\begin{array}{l}\text { Pre-Test } \\
\text { Eksperim } \\
\text { en }\end{array}$ & 143 & 27 &, 162 & ,927 & 27 & ,057 \\
\hline $\begin{array}{l}\text { laj } \\
\text { ar }\end{array}$ & $\begin{array}{l}\text { Pre-Test } \\
\text { Kontrol }\end{array}$ & , 139 & 27 & 197 & ,937 & 27 & , 101 \\
\hline
\end{tabular}

a. Lilliefors Significance Correction

Berdasarkan Tabel 3 diperoleh nilai signifikan kelas eksperimen adalah 0,162 dan kelas kontrol adalah 0,197 yang masing-masing lebih besar dari $\alpha=0,05$ dan nilai $K S_{\text {hitung }}$ pada kelas eksperimen 0,143 dan kelas kontrol 0,139 ternyata masing-masing $K S_{\text {hitung }} \leq$ $K S_{\text {tabel }}(0,254)$. Maka dapat disimpulkan bahwa data pretest berasal dari sampel berdistribusi normal.

Sedangkan perhitungan analisis normalitas data posttest kelas eksperimen dan kelas kontrol dapat dilihat pada Tabel 4 . 
Tabel 4. Uji Normalitas Posttest Kelas Eksperimen dan Kelas Kontrol

\begin{tabular}{|c|c|c|c|c|}
\hline \multicolumn{5}{|c|}{ Tests of Normality } \\
\hline & \multirow[b]{2}{*}{ Kelas } & $\begin{array}{l}\text { Kolmogorc } \\
\text { Smirnov }\end{array}$ & & Shapiro-Wilk \\
\hline & & Statistic df & Sig. & Statistic df Sig. \\
\hline \multirow[t]{2}{*}{$\begin{array}{l}\text { Hasil } \\
\text { Belaja } \\
\mathrm{r}\end{array}$} & $\begin{array}{l}\text { Post- } \\
\text { Test } \\
\text { Eksperi } \\
\text { men }\end{array}$ & ,165 27 &, 057 & $\begin{array}{lll}, 888 & 27 & 007\end{array}$ \\
\hline & $\begin{array}{l}\text { Post- } \\
\text { Test } \\
\text { Kontrol }\end{array}$ &, $143 \quad 27$ & ,165 & ,928 27,062 \\
\hline a. Lilli & efors Sig & ificance Correc & & \\
\hline
\end{tabular}

Berdasarkan Tabel 4 diperoleh nilai signifikan kelas eksperimen dan kontrol masing-masing lebih besar dari $\alpha=0,05$ yaitu 0,057 dan 0,165. Sedangkan untuk nilai $K S_{\text {hitung }}$ pada kelas eksperimen 0,165 dan kelas kontrol 0,143 ternyata masing-masing $K S_{\text {hitung }} \leq K S_{\text {tabel }}(0,254)$. Maka dapat disimpulkan bahwa data posttest berasal dari sampel berdistribusi normal.

Sedangkan untuk analisis normalitas data angket kemandirian belajar siswa pada kelas eksperimen dan kelas kontrol dapat dilihat pada Tabel 5.

Tabel 5. Uji Normalitas Kemandirian Belajar Kelas Eksperimen dan Kelas Kontrol

\begin{tabular}{llcc|c|c|c|c}
\hline \multicolumn{7}{c}{ Tests of Normality } \\
\hline & & \multicolumn{3}{c}{ Kolmogorov- } \\
\cline { 3 - 9 } & Statisti & & Statist & & \\
& Kategori & c & df & Sig. & ic & df & Sig. \\
\hline $\begin{array}{l}\text { Keman } \\
\text { dirian } \\
\text { Belajar }\end{array}$ & Tinggi &, 131 & 40 &, 082 &, 961 & 40 &, 182 \\
\cline { 2 - 9 } & Rendah &, 132 & 14 &, 200 &, 963 & 14 &, 775 \\
\hline
\end{tabular}

*. This is a lower bound of the true significance.

a. Lilliefors Significance Correction

Berdasarkan Tabel 5 diperoleh nilai signifikan pada kategori tinggi yaitu 0,082 dan pada kategori rendah yaitu 0,200 yang masingmasing lebih besar dari $\alpha=0,05$ dan nilai $K S_{\text {hitung }}$ pada kategori tinggi 0,131 dan pada kategori rendah 0,132 ternyata masing-masing $K S_{\text {hitung }} \leq K S_{\text {tabel }}$. Maka disimpulkan bahwa data angket kemandirian belajar siswa berasal dari populasi yang berdistribusi normal.

2) Uji homogenitas

Berdasarkan hasil perhitungan diperoleh output dari analisis uji levene homogenitas data pretest kelas eksperimen dan kelas kontrol diperoleh nilai signifikan $0,904>\alpha=0,05$. Untuk data posttest kelas eksperimen dan kelas kontrol diperoleh nilai signifikan $0,216>\alpha=0,05$. Sedangkan untuk data angket kemandirian belajar siswa diperoleh nilai signifikan 0,119> $\alpha=0,05$. Nilai tersebut menjelaskan bahwa data hasil belajar dan data angket kemandirian belajar siswa pada kelas kontrol dan kelas eksperimen bervariansi homogen.

\section{Hasil dan Pembahasan}

Tabel 6. Hasil Analisis Uji Anava Dua Jalan

\begin{tabular}{|c|c|c|c|c|c|}
\hline \multicolumn{6}{|c|}{ Tests of Between-Subjects Effects } \\
\hline \multicolumn{6}{|c|}{ Dependent Variable: Hasil Belajar Siswa } \\
\hline Source & $\begin{array}{l}\text { Type III } \\
\text { Sum of } \\
\text { Squares }\end{array}$ & df & $\begin{array}{l}\text { Mean } \\
\text { Square }\end{array}$ & $\mathrm{F}$ & Sig. \\
\hline $\begin{array}{l}\text { Corrected } \\
\text { Model }\end{array}$ & $2847,178^{a}$ & 3 & 949,059 & 7,773 &, 000 \\
\hline Intercept & 267319,69 & 1 & 267319,69 & 2189,4 & ,000 \\
\hline $\begin{array}{l}\text { Metode } \\
\text { Pembelajaran } \\
\text { (A) }\end{array}$ & 1271,411 & 1 & 1271,411 & 10,413 & ,002 \\
\hline $\begin{array}{l}\text { Kemandirian } \\
\text { Belajar (B) }\end{array}$ & 1064,735 & 1 & 1064,735 & 8,720 &, 005 \\
\hline $\begin{array}{l}\text { Metode } \\
\text { Pembelajaran } \\
*\end{array}$ & 15,037 & 1 & 15,037 & , 123 &, 727 \\
\hline $\begin{array}{l}\text { Kemandirian } \\
\text { Belajar }(\mathrm{AB}) \\
\end{array}$ & & & & & \\
\hline Error & 6104,822 & 50 & 122,096 & & \\
\hline Total & $\begin{array}{r}383952,00 \\
0 \\
\end{array}$ & 54 & & & \\
\hline $\begin{array}{l}\text { Corrected } \\
\text { Total }\end{array}$ & 8952,000 & 53 & & & \\
\hline
\end{tabular}

Berdasarkan perhitungan uji prasyarat yang dilakukan, data telah memenuhi syarat yaitu berasal dari populasi yang normal dan bervariansi homogen, selanjutnya dilakukan uji analisis data menggunakan uji ANAVA dua jalan dengan sel sama menggunakan software SPSS versi 25.0 for windows. Diperoleh output 
dari analisis uji Anava dua jalan yang disajikan pada Tabel 6.

Berdasarkan Tabel 6 maka hipotesis pada penelitian ini dapat dijawab, yaitu dengan melihat nilai signifikan (sig.) dan nilai $F_{\text {hitung }}$. $H_{0}$ ditolak jika nilai signifikan lebih kecil dari $\alpha$ $=0,05$ dan nilai $F_{\text {hitung }}$ lebih besar dari nilai $F_{\text {tabel }}$.

\subsection{Pengaruh metode pembelajaran flipped classroom berbantuan schoology terhadap hasil belajar siswa SMP Muhammadiyah 5 Surabaya}

Berdasarkan hasil analisis data pada Tabel 6 diperoleh $F_{\text {hitung }}=10,413$ dan nilai signifikan 0,002 . Sedangkan untuk nilai $F_{\text {tabel }}$ dengan $\alpha=$ 0,05 serta df pembilang 1 dan df penyebut 50 diperoleh nilai $F_{\text {tabel }}=4,08$. Karena nilai signifikan $=0,002<\alpha=0,05$ dan $F_{\text {hitung }}=$ $10,413>F_{\text {tabel }}=4,08$ sehingga $H_{0 A}$ ditolak. Maka dapat disimpulkan bahwa terdapat pengaruh penggunaan metode pembelajaran flipped classroom berbantuan schoology terhadap hasil belajar siswa SMP Muhammadiyah 5 Surabaya. Hasil belajar siswa yang memperoleh metode pembelajaran flipped classroom berbantuan schoology lebih baik daripada tidak menggunakan metode pembelajaran flipped classroom berbantuan schoology. Hal tersebut ditunjukkan dari rataan marginal antar baris untuk metode pembelajaran flipped classroom berbantuan schoology yaitu 86,500 dan rataan marginal untuk metode pembelajaran e-learning yang umum digunakan di SMP Muhammadiyah 5 Surabaya dengan bantuan Microsoft teams yaitu 75,339 yang berarti 86,500 > 75,339.

Proses pembelajaran di

SMP Muhammadiyah 5 Surabaya dengan menggunakan metode flipped classroom berbantuan schoology, siswa terlihat siap dan bersikap sewajarnya seperti pembelajaran biasanya. Hal tersebut dikarenakan sehari sebelum proses pembelajaran dimulai telah diadakan sosialisasi mengenai LMS yang akan digunakan dalam pembelajaran. Pada saat proses pembelajaran berlangsung siswa aktif dalam mengikuti pembelajaran, siswa bertukar pendapat dengan teman-temannya, dan siswa juga turut aktif dalam menjawab pertanyaan yang diberikan oleh guru dikarenakan siswa telah memiliki pemahaman mengenai materi pada saat pembelajaran berlangsung. Guru pada saat proses pembelajaran hanya sebagai fasilitator dan pendamping siswa, dimana apabila salah satu siswa kesulitan untuk menjawab atau terdapat siswa yang bertanya maka yang membantu dan menjawab pertanyaan tersebut adalah teman-temannya terlebih dahulu. Jika memang siswa masih mengalami kesulitan ataupun kebingungan maka guru akan sedikit memberi arahan. Dengan ini interaksi guru dan siswa dapat meningkat dan tujuan pembelajaran yang ingin dicapai dengan waktu pembelajaran yang singkat dapat berjalan dengan maksimal. Hal tersebut sejalan dengan pendapat Nedeva dkk bahwa manfaat dari penggunaan flipped classroom salah satunya adalah meningkatnya interaksi antara guru dan siswa [17].

\subsection{Pengaruh antara kemandirian belajar tinggi dan kemandirian belajar rendah terhadap hasil belajar siswa SMP Muhammadiyah 5 Surabaya}

Berdasarkan hasil analisis data pada Tabel 6 memberikan hasil $F_{\text {hitung }}=8,720$ dan nilai signifikan 0,005 . Sedangkan untuk nilai $F_{\text {tabel }}$ dengan $\alpha=0,05$ serta $\mathrm{df}$ pembilang 1 dan $\mathrm{df}$ penyebut 50 diperoleh nilai $F_{\text {tabel }}=4,08$. Karena nilai signifikan $=0,005<\alpha=0,05$ dan $F_{\text {hitung }}=8,720>F_{\text {tabel }}=4,08$ sehingga $H_{0 B}$ ditolak. Maka dapat disimpulkan bahwa terdapat pengaruh antara kemandirian belajar tinggi dan kemandirian belajar rendah terhadap hasil belajar siswa SMP Muhammadiyah 5 Surabaya. diketahui bahwa rataan marginal antar kolom untuk kemandirian belajar siswa tinggi yaitu 86,027 dan rataan marginal antar kolom untuk kemandirian belajar siswa rendah yaitu 75,813 yang berarti 86,027> 75,813. Perbedaan yang signifikan juga disebabkan 
karena siswa dengan kemandirian belajar kategori tinggi memiliki sikap disiplin dan aktif pada saat proses pembelajaran. Hal tersebut juga sejalan dengan penelitian terdahulu bahwa siswa yang memiliki tingkat kemandirian belajar yang baik maka akan memiliki hasil belajar yang maksimal $[8,18,19]$.

\subsection{Interaksi penggunaan metode pembelajaran dan kemandirian belajar terhadap hasil belajar siswa SMP Muhammadiyah 5 Surabaya.}

Berdasarkan hasil analisis data pada Tabel 6 data diperoleh $F_{\text {hitung }}=0,123$ dan nilai signifikan 0,727 . Sedangkan untuk nilai $F_{\text {tabel }}$ dengan $\alpha=0,05$ serta $\mathrm{df}$ pembilang $1 \mathrm{dan} \mathrm{df}$ penyebut 50 diperoleh nilai $F_{\text {tabel }}=0,123$. Karena nilai signifikan $=0,727>\alpha=0,05$ dan $F_{\text {hitung }}=0,123<F_{\text {tabel }}=4,08$ sehingga $H_{0 A B}$ diterima. Maka dapat disimpulkan bahwa tidak terdapat interaksi penggunaan metode pembelajaran dan kemandirian belajar terhadap hasil belajar siswa. Secara teori dijelaskan bahwa hal yang dapat mempengaruhi hasil belajar siswa diantara lain metode pembelajaran dan kemandirian belajar sebagaimana pendapat Setyosari dalam Mudlofir dkk bahwa faktorfaktor yang mempengaruhi hasil belajar adalah sifat atau karakteristik siswa yang mencakuup kemandirian siswa, pemberian tugas oleh guru dan metode pembelajaran [20]. Namun, hasil penelitian yang dilakukan terlihat bahwa tidak terdapat interaksi antara metode pembelajaran flipped clasroom dan kemandirian belajar siswa terhadap hasil belajar siswa. Ketidaksesuaian hasil penelitian dengan teori tersebut memungkinkan karena siswa tidak jujur ataupun asal-asalan dalam mengisi angket. Hal tersebut berpengaruh terhadap hasil yang tidak sesuai dengan teori, yang seharusnya terdapat interaksi antara metode pembelajaran flipped clasroom dan kemandirian belajar terhadap hasil belajar siswa SMP Muhammadiyah 5 Surabaya.

\subsection{Analisis Aktivitas Siswa}

Berdasarkan analisis data aktivitas siswa pada kelas eksperimen diperloeh persentase aktivitas siswa secara klasikal yaitu $66,07 \%$ berada pada kategori cukup aktif. Berdasarkan rata-rata persentase tiap aspek diperoleh aktivitas yang dominan yaitu adalah memperhatikan penjelasan guru/teman dengan persentase $65,30 \%$. Aktivitas dominan yang kedua yaitu mengumpulkan pre-test, tugas, dan post-test tepat waktu dengan persentase $37,53 \%$. Hal tersebut menandakan bahwa siswa paham akan materi sehingga mereka dengan mudah mengerjakan soal-soal yang ada. Aktivitas dominan yang ketiga yaitu mengajukan atau menjawab pertanyaan dari guru atau teman pada saat proses pembelajaran dengan persentase $15,34 \%$. Hal tersebut menandakan bahwa siswa aktif dalam proses pembelajaran dikarenakan mereka telah memiliki pengetahuan dan pemahaman mengenai materi sebelum dilaksankan proses pembelajaran tatap muka melalui video pembelajaran yang diberkan oleh guru sebelumnya. Sedangkan rata-rata persentase aktivitas siswa yang sedikit dilakukan selama pembelajaran yaitu Perilaku yang tidak relevan pada saat pembelajaran online (offline sebelum waktunya, tidak merespon pada saat ditanya) dengan persentase $0,80 \%$.

\section{Penutup}

Berdasarkan uraian di atas, dapat diambil kesimpulan bahwa: (1) hasil belajar siswa yang menggunakan metode pembelajaran flipped classroom berbantuan schoology lebih baik dibandingkan dengan yang tidak menggunakan metode pembelajaran flipped classroom berbantuan schoology. Aktivitas siswa yang menggunakan metode pembelajaran flipped classroom berbantuan schoology secara klasikal diperoleh hasil $66,07 \%$ berada pada kategori cukup aktif. (2) Hasil belajar siswa yang memiliki kemandirian belajar tinggi lebih baik daripada siswa yang memiliki kemandirian belajar rendah. Semakin tinggi kemandirian belajar siswa semakin maksimal hasil belajar siswa. (3) Berdasarkan hasil analisis data 
menggunakan uji ANOVA dua arah tidak terdapat interaksi antara metode pembelajaran dengan tingkat kemandirian belajar siswa terhadap hasil belajar siswa.

\section{Referensi}

[1] A. W. Abdullah, N. Achmad and N. C. Fahrudin, "Deskripsi hasil belajar matematika siswa melalui pembelajaran daring pada pokok bahasan bangun ruang sisi datar," EULER: Jurnal Ilmiah Matematika, Sains dan Teknologi, vol. 8 No.2, pp. 36-41, Desember 2020.

[2] A. Legiman, "Peningkatan disiplin dan hasil belajar matematika pada pembelajaran tatap muka masa pandemi covid 19 dengan tugas terstruktur," Inopendas Jurnal Ilmiah Kependidikan, vol. 4 No.1, pp. 28-33, Februari 2021.

[3] H. Tambunan, "Dampak pembelajaran online selama pandemi covid-19 terhadap resiliensi, literasi matematis dan prestasi matematika siswa," Jurnal Pendidikan Matematika Indonesia, vol. 6 No.2, pp. 70-76, September 2021.

[4] M. Afandi, E. Chamalah and O. P. Wardani, Model Dan Metode Pembelajaran Di Sekolah, pertama ed., Semarang: UNISSULA Press, 2013.

[5] M. Kurniawati, H. Santanapurba and E. Kusumawati, "Penerapan Blended Learning Menggunakan Model Flipped Classroom Berbantuan Google Classroom Dalam Pembelajaran Matematika SMP," EDU-MAT, vol. 7 No.1, April 2019.

[6] M. P. Kurniawidi and M. F. T. G. Nakita, "Pengembangan Pembelajaran Flipped Classroom Dengan Memanfaatkan LMS Kelase Topik Menggambar Grafik Fungsi SMP Kelas VIII," in Seminar Nasional Etnomatnesia, Yogyakarta, 2018.

[7] Suid, A. Syafrina and Tursinawati, "Analisis Kemandirian Siswa Dalam Proses Pembelajaran Di Kelas III SD Negeri 1 Banda Aceh," Jurnal Pesona Dasar, vol. 1 No. 5, April 2017.

[8] N. Handayani and F. Hidayat, "Hubungan Kemandirian Terhadap Hasil Belajar Siswa
Mata Pelajaran Matematika Di Kelas X Smk Kota Cimahi," Jurnal On Education, vol. 1 No 2, pp. 1 - 8, Februari 2018.

[9] M. Jauhar, Implementasi Paikem Dari Behavioristik Sampai Konstruktivistik Sebuah Pengembangan Pembelajaran Berbasis Ctl (Contextual Teaching \& Learning), Jakarta: Prestasi Pustaka, 2011, p. 193.

[10] S. Amri, Pengembangan \& Model Pembelajaran dalam Kurikulum 2013, Jakarta: Prestasi Pustaka, 2013.

[11] Nurdyansyah and E. F. Fahyuni, Inovasi Model Pembelajaran Sesuai Kurikulum 2013, Sidoarjo: Nizamial Learning Center, 2016.

[12] N. W. M. A. Putri, N. Jampel and I. K. Suartama, "Pengembangan E-Learning Berbasis Schoology pada Mata Pelajaran IPA Kelas VIII ddi SMP Negeri 1 Seririt," Journal Edutech Universitas Pendidikan Ganesha, vol. 2 No. 1, 2014.

[13] M. S. Ulfi, I. Holisin and E. Suprapti, "Meningkatkan Hasil Belajar Matematika Melalui Model Pembelajaran Blended Learning Berbasis Schoology Di SMA Muhammadiyah 2 Surabaya," in Seminar Nasional Pendidikan Matematika HIMAPTIKA UMSurabaya, Surabaya, 2019.

[14] N. F. Zatalini, I. Minggi and Rusli, "Pengaruh Strategi Pembelajaran Flipped Classroom Menggunakan e-Learning Kelase Terhadap Hasil Belajar Matematika Siswa," Issues in Mathematics Education, vol. 1 No.2, September 2017.

[15] Choirudin, "Efektivitas Pembelajaran Berbasis Schoology," Numerical:Jurnal Matematika dan Pendidikan Matematika, vol. 1 No. 2, pp. 52-56, Desember 2017.

[16] Z. Aqib, Penelitian Tindakan Kelas, Bandung: Yrama Widya, 2006.

[17] V. Nedeva, S. Dineva and Z. Ducheva, "Students In Blended Learning By Flipped Classroom Approach," Information Technologies and Learning Tools, vol. 72 No.4, pp. 2014 - 2013, 2019.

[18] R. Ningsih and A. Nurrahmah, "Pengaruh kemandirian belajar dan perhatian orang tua terhadap prestasi belajar matematika," Jurnal Formatif, vol. 6 No.1, pp. 73-84, 2016. 
[19] A. P. Laksana and H. S. Hadijah, "Kemandirian belajar sebagai determinan hasil belajar siswa," JURNAL PENDIDIKAN MANAJEMEN PERKANTORAN, vol. 4 No.1, pp. 1-7, Januari 2019.
[20] A. Mudlofir and E. F. Rusdiyah, Desain Pembelajaran Inovati: Dari Teori ke Praktik, 2 ed., Jakarta: Rajawali Press, 2017. 
